It is to be hoped that this will be the first of many similar courses in fire control and that eventually a certificate of competence will be required of all forest fire wardens in British Columbia.

Contributed by J. H. G. SMITH

\title{
World EnToMology Congress for CANAdA
}

The Tenth International Congress of Entomology is to be held next summer in Montreal, August 17-25, when the world's foremost entomologistssome 1,500 of them from about 60 countries-will review progress made in controlling destructive pests in forestry, agriculture, manufactured food products, human welfare and other fields.

The Congress, which will be held at McGill University and the University of Montreal, is under the patronage of His Excellency the Governor General of Canada and the national host organization is the Entomological Society of Canada. Serving on the Congress Honorary Committee are The Rt. Hon. James G. Gardiner, Federal Minister of Agriculture, J. G. Taggart, Deputy Minister of Agriculture, and K. W. Neatby, Director, Science Service, Canada Department of Agriculture; serving from the Province of Quebec are Hon. Laurent Barré, Minister of Agriculture, and Hon. J. S. Bourque, Minister of Lands and Forests, as well as His Worship Jean Drapeau, Mayor of Montreal, F. Cyril James, President and Vice-Chancellor of McGill University, Mgr. Irénée Lussier, Rector of the University of Montreal, and H. G. Dion, Viceprincipal of Macdonald College.

Being held in Canada for the first time, the Congress is of direct interest to all associated with forestry and the wood-products industries. One of its main objectives - the solving of forest insect problems and the minimizing of the damage caused by destructive pests of forests-is of mutual concern to both industrialists and scientists in their endeavors to promote forest conservation and the economical utilization of our forest products.

The program of the 1956 Congress will be divided into 15 sections of which forest, agricultural, medical and veterinary and stored products entomology along with biological control and apiculture are directly concerned with the practical and economical aspects of national welfare. At the same time the highly scientific aspects of entomology will be covered in special sections. Costs of the undertaking are being met by federal and provincial grants and the generous support of the City of Montreal, the host universities, UNESCO, and an increasing number of commercial organizations and scientific societies.

The 1956 Congress will mean much to technologists engaged in all fields of applied entomology. Leading world scientists will have the opportunity of personally exchanging views on important problems, and assessing the results of entomological research, teaching achievements, and latest methods of controlling destructive pests.

\section{C. BUCKLAND}

On February 15th, 1956, Donald Channing Buckland passed away quietly in Vancouver General Hospital, at the age of 38 years. He is survived by his wife, Kirstine, and three children aged 8,5 and 2 years. 